\title{
INTEGRATED APPROACH TO SOLVING THE FLUID DYNAMICS AND HEAT TRANSFER PROBLEMS
}

The dynamics' problems embrace an important branch of applied sciences. A large part of researchers' efforts is devoted to their solution that is due not only to these problems' diversity, but also the solutions complexity.

Analysis of recent research and publications. Changing the investigated parameters in time and space is considered by researchers as the need to write the original mathematical model in differential form. So let we call this approach "differential" one. Further the efforts are focused onto simplifying the model maintaining a certain degree of adequacy of the studied process description. That is usually done through minimum possible simplification, allowing required solution obtaining in one way or another. Contemporary level of mathematical apparatus and computer technology development make possible to obtain numerical solutions for, complex models. This leads to taking into account the thin phenomena. In some cases it is necessary and furthermore, it represents the research aim. But often their inclusion does not have any significant impact on the studied process' basic parameters value, at the same time being a major source of difficulties when solving and resource expenses. Moreover, taking into account insignificant factors does disguise the fundamental phenomena manifestation and complicates forecasting their development in a wide range of input data changes.

In many cases, there is an alternative to the above approach. Let we define it as an "integral" one. It is based on balance conservation equations (momentum, matter, energy) registered in the general integral form, or, in other words, in a concentrated formulation. Subsequently, there takes place an effect of mathematical model elements complication (and not the simplification as in the "differential" approach). The detailing reaches a minimum required level of the obtained solution accuracy. Often these models solution are much simpler than these obtained through "differential" approach and, in addition, at all stages of the model transformation the studied variables integral balances are the same. Their distribution can be described by simple a priori relations with an accuracy up to the least coefficients' quantity. The nature of dependencies can be determined from simple model experiments or from previously obtained partial (often complex) solutions. The coefficients are determined from a small number of the analogic experiments. This approach does involve some approximations and therefore some errors. But to be noted is that in applied problems solving the respective values' measurements also produce some error. Therefore some inaccuracy of such calculations is acceptable, although its scale must be evaluated. At these calculations' issue we can obtain a simple relation amenable to a broad generalization and useful when calculating the unknown values.

Aim of the Research. This research has been aimed onto considering the "integral" approach to solving problems of dynamics, with further illustration of the "integral" approach possibilities to problem solving at examples:

- problem of determining the natural frequencies of fluctuations case of the free surface liquid in containers of various shapes;

- problem of determining the transitory process time at various bodies heating (plate, cylinder, sphere).

Main Body. The early beginning of search for efficient solutions of problems concerning natural frequency determination of the fluid with a free surface in different shapes' containers dates back to the XIX century [1], that search continued throughout the XX century. Even today this issue still never

DOI 10.15276/opu.2.44.2014.21

(C) A.I. Brunetkin, 2014

ЕНЕРГЕТИКА. ТЕПЛОТЕХНІКА. ЕЛЕКТРОТЕХНІКА 
lost its practical significance. The oscillating fluid can influence (causing often a negative impact onto) the condition of $\mathrm{r} / \mathrm{w}$ and automobile transport tanks (most $\mathrm{r} / \mathrm{w}$ accidents does occur namely with tanks), tankers, liquid fuel storage reservoir at oil storage and distribution terminals, nuclear fuel storage pools, etc. In these last two cases, the fluid fluctuation can be due to the seismic action [2]. The problem solution was often searched by variational or experimental [3] methods. Those solution being in principle found, they essentially relate to particular cases [3], or give a complex sophisticated tool for problem solving, which still needs for some advanced skill to use, and, when used, still gives a partial result. That doesn't allow making, on the basis of such solutions, some general conclusions for different forms of containers or varying degrees of reservoir filling.

Let we consider the integral approach. Its use requires determining the nature of the fluid in the container. To this end, we implement the visualization of its inner layers' movement when free surface vibrational motion. This can be done by placing in the container's center a rod coloring the fluid's surrounding layers (Fig. 1). The resulting picture (colored liquid) shows that it is possible to allocate a depth at which the lower (deeper) layers of fluid are not involved into motion; a so-called effective depth. This movement type can be

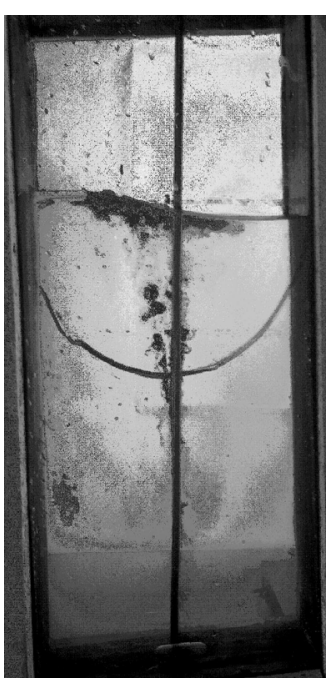

Fig. 1. Visualization of the fluid's internal layers motion observed in different forms vessels, a list of container shapes studied being given at Table 1. Let we admit an effective depth $h_{\text {eff }}$ equal to half the width of the container (Fig. 1: enveloped with a circular arc). To describe the fluid motion we shall apply integral coefficients, using transformations given at [1],

$$
\omega=\sqrt{\frac{n g}{R}} \cdot \sqrt{\bar{h}_{\mathrm{eff}}} \cdot k_{\omega},
$$

where $\bar{h}_{\text {eff }}$ - relative effective depth of the container filling (depth at which the free surface oscillation takes its effect):

$$
\bar{h}_{\mathrm{eff}}=\left\{\begin{array}{l}
1-e^{-k_{\phi} \bar{h}}, \text { at } \bar{h}<1 ; \\
1, \text { at } \bar{h}>1
\end{array}\right.
$$

$\omega$ - proper (circular) frequency of the liquid free surface fluctuations;

$n$ - overload (under normal conditions on the ground $n=1$ );

$g=9,8$ - free-fall acceleration, $\mathrm{m} / \mathrm{s}^{2}$;

$\bar{h}=h / R$-relative depth of container filling;

$h$ - depth of container filling;

$R$-characteristic size of the container (radius for cylindrical container, half the width for a rectangular one).

This approach can be applied to containers of various shapes. The ratio $k_{\omega}$ may be determined by assessing each of values inbounds to the expression. A simpler and more defined methods to find $k_{\omega}$ and $k_{\phi}$, relies upon small experimental series implementing with further results' treatment using the expressions (1) and (2). This is the approach used in [1], which results are shown at Table 1.

Timing of the transition process during the bodies' heating (plate, cylinder, sphere). The aboveexposed problem describes the nature of fluid velocity changes, depending on the depth, on the basis of simple experiments by this motion visualization. But we can select a group of problems whose solution can be built on the basis of existing data and assumptions based on those data, as to the nature of changes in the studied value. Let we consider this approach application to the problem of bodies' cooling and heating. There exists an exact solution for their simple forms: infinite plate, infinite cylinder, 
sphere. This allows us from one hand to estimate the solution's simplification, from another, to evaluate the introduced error.

Table 1

Coefficients' value for calculating the natural frequencies of liquid oscillation in the tanks

\begin{tabular}{r|l|r|r|r}
\hline № & \multicolumn{1}{|c|}{ Tank’s shape, position and influencing forces' directions } & $k_{\phi}$ & $k_{\omega}$ & $\begin{array}{l}\text { The law of distribution of } \\
\text { the calculated results' } \\
\text { normalized deviations } \\
\text { from the experimental one }\end{array}$ \\
\hline 1 & $\begin{array}{l}\text { Straight rectangular parallelepiped, the lateral faces are vertical, } \\
\text { along the side edges, } \bar{h} \geq 0,3\end{array}$ & 3,67 & 1,26 & $(0,011 ; 0,00042)$ \\
\hline 2 & $\begin{array}{l}\text { Circular cylinder the axis is vertical, perpendicularly to the axis, } \\
\bar{h} \geq 0,4\end{array}$ & 4,29 & 1,36 & $(0 ; 0,00064)$ \\
\hline 3 & $\begin{array}{l}\text { Circular cylinder the axis is horizontal lengthwise the axis, } \\
0,2 \leq \bar{h} \geq 3,\end{array}$ & 3,5 & 1,6 & $(0 ; 0,0028)$ \\
\hline 4 & $\begin{array}{l}\text { Circular cylinder the axis is horizontal, perpendicularly to the } \\
\text { axis } 0,2 \leq \bar{h} \geq 1,8\end{array}$ & 2,43 & 1,29 & $(0 ; 0,00037)$ \\
\hline 5 & $\begin{array}{l}\text { Truncated cone the axis is vertical, opening angle } 20^{\circ}, \text { perpen- } \\
\text { dicularly to the axis }\end{array}$ & 5 & 1,21 & $(0 ; 0,000676)$ \\
\hline 6 & $\begin{array}{l}\text { Truncated cone the axis is vertical, opening angle } 50^{\circ}, \text { perpen- } \\
\text { dicularly to the axis }\end{array}$ & 7,57 & 0,905 & $(0 ; 0,000525)$ \\
\hline 7 & $\begin{array}{l}\text { Coaxial circular cylinders the axis is vertical, perpendicularly to } \\
\text { the axis } \bar{h} \geq 0,4\end{array}$ & 4,3 & 1,39 & $(0,02 ; 0,001)$ \\
\hline
\end{tabular}

Considering the temperature changes in the center of a heated body, we can write the initial data in the standard formulation [4]:

- all temperatures values are sought as deviations (on the surface $\vartheta_{\mathrm{s}}$, in the center of the body $\vartheta_{c}$, at the environment $\vartheta_{\text {env }}$ and the mean temperature around the body $\widehat{\vartheta}$ ) respectively to the initial body temperature. In this case

$$
\begin{gathered}
\vartheta_{\mathrm{s}}=t_{\mathrm{s}}-t_{0} ; \\
\vartheta_{\mathrm{c}}=t_{\mathrm{c}}-t_{0} ; \\
\vartheta_{\mathrm{env}}=t_{\mathrm{env}}-t_{0}=\mathrm{const} ; \\
\widehat{\vartheta}=\widehat{t}-t_{0},
\end{gathered}
$$

where $t_{\mathrm{s}}$ - the heated body surface temperature;

$t_{\mathrm{c}}$ - temperature at the center of the body during heating;

$\bar{t}$ - mean-body temperature during heating;

- before heating beginning the body is in equilibrium with environment having a temperature $t_{0}$. At the initial instance the ambient temperature changes abruptly from $t_{0}$ to $t_{\mathrm{env}}=$ const ;

- the reference center corresponds to the body center;

- the III type conditions being the most common kind are taken as the boundary conditions.

It is known that the process of bodies' heating - cooling when considering their cross-section temperature as the equilibrium temperature is exponential. The exact solution for the case of nonequilibrium temperature distribution as given in [4], although not the same for different forms of the bodies, does also bear an exponential component. In [4] the solutions obtained in the form of some series underwent a simplification on the grounds that, even for Fo $\geq 0,3$ the series are rapidly con- 
verging therefore the temperature distribution is rather accurately described by the first term of the series. That results in:

- for plate center

$$
\bar{\vartheta}_{c}=\frac{2 \cdot \sin \mu_{1}}{\mu_{1}+\sin \mu_{1} \cdot \cos \mu_{1}} \exp \left(-\mu_{1}^{2} \mathrm{Fo}\right),
$$

where Fo - Fourier number;

$\mu_{1}$ - the first root of the solution for transcendental equation $\operatorname{ctg} \mu=\mu / B i$;

$\mathrm{Bi}$ - Biot criterion;

$\bar{\vartheta}_{\mathrm{c}}=\vartheta_{\mathrm{c}} / \vartheta_{\text {env }}$ - normalized temperature at the center;

— for cylinder center

$$
\bar{\vartheta}_{\mathrm{c}}=\frac{2 \cdot J_{1}\left(\mu_{1}\right)}{\mu_{1}\left[J_{0}^{2}\left(\mu_{1}\right)+J_{1}^{2}\left(\mu_{1}\right)\right]} \exp \left(-\mu_{1}^{2} \mathrm{Fo}\right)
$$

where $\mathrm{J}_{0}$ and $\mathrm{J}_{1}-$ Bessel function of zero and first order, respectively;

$\mu_{1}$ - the first root of the solution for transcendental equation $\frac{J_{0}(\mu)}{J_{1}(\mu)}=\frac{\mu}{\mathrm{Bi}}$;

- for sphere center:

$$
\bar{\vartheta}_{\mathrm{c}}=\frac{2 \cdot\left(\sin \mu_{1}-\mu_{1} \cos \mu_{1}\right)}{\mu_{1}-\sin \mu_{1} \cos \mu_{1}} \exp \left(-\mu_{1} \mathrm{Fo}\right),
$$

where $\mu_{1}$ - the first root of the solution for transcendental equation $\operatorname{tg}(\mu)=(-\mu) /(\mathrm{Bi}-1)$.

Assuming that the $\vartheta_{x}$ change from $\vartheta_{s}$ to $\vartheta_{c}$ has an exponential character, let we suppose that for different embodiments of the heating process its parameters expression form remains the same when quantitative changes. We represent that in the form of

$$
\vartheta_{x}=\vartheta_{c}+\left(\vartheta_{s}-\vartheta_{c}\right) \exp \left(1-\frac{l}{x}\right) \text {. }
$$

The $\vartheta_{\mathrm{s}}$ and $\vartheta_{\mathrm{c}}$ values are unknown, therefore subject to determining. The expression (6) is written considering the fact that at $x=l$ there would be $\vartheta_{x}=\vartheta_{s}$ and at $x=0$ the necessary condition is $\vartheta_{x}=\vartheta_{c}$. Here $l$ represents a characteristic size of the studied body, and $x$ is the current coordinate from the body center to its surface.

The average integral temperature value

$$
\widehat{\vartheta}=\frac{1}{V_{T}} \int_{0}^{l} \vartheta_{x} S_{x} d x
$$

and mean-distance $\hat{l}$ from the reference zero, where the sought temperature is conventionally implemented

$$
\hat{l}=\frac{1}{V_{T}} \int_{0}^{l} x \cdot \exp \left(1-\frac{l}{x}\right) \cdot S_{x} d x,
$$

where $V_{T}$ — the heated body volume;

$S_{x}$ - area of the layer parallel to the body surface at the distance $x$ from the coordinates' origin. Let we consider the plate heating. Due to its symmetry we estimate the heating through only one side surface and half of the thickness. In this case

$$
V_{T}=S_{\text {lat }} \cdot \delta
$$

where $S_{\text {lat }}$ - area of the plate's lateral surface;

$\delta-1 / 2$ thickness of the plate.

Substituting (6) into (7), (8) and performing the necessary transformations, we obtain

$$
\widehat{\vartheta}=\vartheta_{c}+\left(\vartheta_{s}-\vartheta_{c}\right) k,
$$


where $k=0,4$;

$$
\widehat{\delta}=k \cdot \delta
$$

$\widehat{\delta}$ - mean-distance from the coordinates' origin, at which conditionally realized is the temperature $\widehat{\vartheta}$.

With regard to (9) and (10) the body heating model can be compactly written down through parametric representation as

$$
\begin{gathered}
c \rho V_{T} \frac{d \hat{\vartheta}}{d \tau}=S_{\text {lat }} \frac{\lambda}{\delta}\left(\vartheta_{\mathrm{s}}-\widehat{\vartheta}\right), \\
\frac{\lambda}{\bar{\delta}} S_{\mathrm{lat}}\left(\vartheta_{\mathrm{s}}-\widehat{\vartheta}\right)=\alpha S_{\mathrm{lat}}\left(\vartheta_{\mathrm{env}}-\vartheta_{\mathrm{s}}\right),
\end{gathered}
$$

where $\tau$ - current process time;

$c$ - specific heat capacity of the heated body;

$\rho$ - substance density;

$\lambda$ - substance heat conductivity;

$\alpha$ - coefficient of heat transfer from the body to the environment.

The equation (11) expresses the law of energy conservation. Its right side determines the energy transferred from the boundary (surface body) inside by a difference (pressure) in thermodynamic force (temperature difference) capacity. The left part serves to express the energy stored due to body capacity (specific heat).

The equation (12) exposes III type boundary condition and represents the energy balance. The right part describes the energy transferred from the environment to the body. The left one, similarly to the previous equation, refers to the energy drawn from the surface into the body. At that $\alpha$ is the coefficient of heat transfer from the environment to the body; $\lambda$ renders the thermal conductivity of the body material; $\rho$ is the density; and $c$ is the specific heat of the heated body material.

After transformation of (11) and (12) equations, taking into account expressions (9) and (10)

$$
\bar{\vartheta}_{\mathrm{c}}=1-\exp (-\hat{\mathrm{H} o})
$$

where Ho - modified homochronicity index:

$$
\widehat{\mathrm{H} o}=\frac{a \tau}{\delta^{2}} \frac{S_{\mathrm{lat}} \delta}{V_{T}} \frac{\mathrm{Bi}}{1+k \mathrm{Bi}} \quad \text { or } \quad \hat{\mathrm{H} o}=\mathrm{Fo} \frac{S_{\mathrm{lat}} \delta}{V_{T}} \frac{\mathrm{Bi}}{1+k \mathrm{Bi}} ;
$$

where $a=\frac{\lambda}{c p}$ - heat conductivity coefficient;

$\mathrm{Bi}=\frac{a \delta}{\lambda}-$ Biot criterion;

Fo -Fourier criterion.

Herein:

— for plate

$$
\frac{S_{\mathrm{lat}} \delta}{V_{T}}=\frac{S_{\mathrm{lat}} \delta}{S_{\mathrm{lat}} \delta}=1
$$

— for infinite cylinder

$$
\frac{S_{\mathrm{lat}} R}{V_{T}}=\frac{2 \pi R L R}{\pi R^{2} L}=2,
$$

where $L$ - cylinder length;

- for sphere

$$
\frac{S_{\mathrm{lat}} R}{V_{T}}=\frac{4 \pi R^{2} R}{\frac{4}{3} \pi R^{3}}=3 .
$$


We shall apply the solution (13), (14) to estimate the bodies' heating transitory process end. After that we compare the results with the known exact solutions of [4]. Departing from (13) the transition process is considered complete when $\hat{\mathrm{H}} \mathrm{o}=3$. This corresponds to the sought value deviation from its maximum possible value ( 1 in this case) never exceeding $5 \%$, i.e. $\bar{\vartheta}_{\mathrm{c}}=0,95$. For this case, (15)

$$
\mathrm{Fo}_{1}=\frac{\hat{\mathrm{Ho}}}{\frac{S_{\mathrm{lat}} \delta}{V_{T}} \frac{\mathrm{Bi}}{1+k \mathrm{Bi}}} .
$$

Now we adjust the value $k$ rounded in (9) using exact solutions [4]. As a result, we obtain:

— for plate $k=0,42$;

- for cylinder $k=0,39$;

- for sphere $k=0,36$.

Results. Now we proceed to comparing the results $\mathrm{Fo}_{1}$ and $\mathrm{Fo}_{2}$ and, thus the heating process end time based on relative error given in Table 2.

Table 2

Comparison of exact and approximate values of the heating process end time

\begin{tabular}{c|c|c|c|c|c|c|c|c|c}
\hline \multirow{2}{*}{$\mathrm{Bi}$} & \multicolumn{3}{|c|}{ Plate $k=0,42$} & \multicolumn{3}{c|}{ Cylinder $k=0,39$} & \multicolumn{3}{c}{ Sphere $k=0,36$} \\
\cline { 2 - 12 } & $\mathrm{Fo}_{2},[4]$ & $\begin{array}{c}\mathrm{Fo}_{1}, \\
\text { Calcul.(20) }\end{array}$ & $\varepsilon, \%$ & $\mathrm{Fo}_{2},[4]$ & $\begin{array}{c}\mathrm{Fo}_{1}, \\
\text { Calcul.(20) }\end{array}$ & $\varepsilon, \%$ & $\mathrm{Fo}_{2},[4]$ & $\begin{array}{c}\mathrm{Fo}_{1}, \\
\text { Calcul.(20) }\end{array}$ & $\varepsilon, \%$ \\
\hline 0,005 & 600,34 & 601,26 & 0,15 & 300,06 & 300,6 & 0,18 & 200,1 & 200,4 & 0,15 \\
\hline 0,01 & 300,9 & 301,3 & 0,1 & 150,4 & 150,6 & 0,15 & 100,20 & 100,36 & 0,17 \\
\hline 0,1 & 31,12 & 31,26 & 0,5 & 15,48 & 15,59 & 0,7 & 10,29 & 10,36 & 0,7 \\
\hline 1,0 & 4,200 & 4,26 & 1,4 & 2,02 & 2,085 & 3,3 & 1,31 & 1,36 & 3,7 \\
\hline 10 & 1,58 & 1,56 & 1,3 & 0,725 & 0,735 & 1,3 & 0,45 & 0,46 & 1,4 \\
\hline 100 & 1,34 & 1,29 & 3,6 & 0,612 & 0,6 & 1,9 & 0,38 & 0,37 & 3,0 \\
\hline 1000 & 1,32 & 1,26 & 3,9 & 0,601 & 0,587 & 2,36 & 0,37 & 0,36 & 3,4 \\
\hline
\end{tabular}

In the whole range of changes $\mathrm{Bi}$ for all bodies considered the time of the heating process end, calculated using the proposed model, when compactly formulated differs from the results of the exact model solution in a distributed setting for less than $4 \%$, i.e. complies with the engineering calculations precision tolerance. At that the transitory process' end is defined by a single value Ho $=3$, while the source [4] assigns in this case to each body and each Bi value a corresponding value Fo.

Thus, the bodies heating end time for considered shapes can be determined using one expression (13) and two coefficients (Table 3), which is much simpler than when using exact solutions of (3), (4), (5) type.

Table 3

Shape coefficients

\begin{tabular}{c|c|c}
\hline & $\frac{S_{\text {lat }}}{V_{T}}$ & $k$ \\
\hline Plate & 1 & 0,42 \\
\hline Cylinder & 2 & 0,39 \\
\hline Sphere & 3 & 0,36 \\
\hline
\end{tabular}

Conclusions. At this study issue we came to get a single solution in the form (1) for the problem of determining the fluctuations natural frequencies for fluid with a free surface, or (13) for the bodies heating problem; this efficient result has been obtained as consequence of the transition to a compactformulation model and use of the investigated parameters' profiles a priori description: 
— In dealing with the problem of estimating the fluid's proper fluctuations frequency as obtained from the visualization of the studied process;

- In solving the problem of bodies' heating on the basis of previously obtained solutions of similar problems.

The resulting solutions are simple, uniform for whole range of considered problems, at that their errors do not exceed the allowable values for engineering calculations accuracy.

\section{Література}

1. Максимов, М.В. Определение собственной частоты колебаний жидкости со свободной поверхностью в емкостях сложных форм / М.В. Максимов, А.И. Брунеткин, Т.С. Добровольская // Вісн. НТУ “ХПІ". Сер.: Математичне моделювання в техніці та технологіях. - 2012. - № 27. C. $134-143$.

2. Гнитько, В.И. Численное моделирование плесканий жидкости в упругой цилиндрической оболочке / В.И. Гнитько, В.В. Науменко // Вісн. ХНУ. Сер.: Математичне моделювання. Інформаційні технології. Автоматизовані системи управління. - 2012. - Вип. 19. - С. $66-72$.

3. Богомаз, Г.И. Колебания жидкости в баках: методы и результаты экспериментальных исследований: сборник научных трудов / Г.И. Богомаз, С.А. Сирота; Нац. акад. наук Украины, Нац. косм. агентство Украины, Ин-т техн. механики. - Днепропетровск: Ин-т техн. механики, 2002. - 305 с.

4. Лыков, А.В. Теория теплопроводности / А.В. Лыков. - М.: Высшая школа, 1967. - 600 с.

\section{References}

1. Maksimov, M.V., Brunetkin, A.I. and Dobrovolskaya, T.S. (2012). Definition of own frequency of fluctuations of a liquid with a free surface in capacities of complex forms. Herald of the National Technical University "Kharkiv Polytechnic Institute": Mathematical modeling in technique and technologies, 27, 134-143.

2. Gnitko, V.I. and Naumenko, V.V. (2012). Numerical simulation of sloshing in elastic cylindrical shell. Bulletin of Kharkiv National University: Mathematical modeling. Information technology. Automated control systems, 19, 66-72.

3. Bogomaz, G.I. and Sirota, S.A. (2002). Oscillations of the Liquid in the Tanks: Methods and Results of Experimental Studies. Dniepropetrovsk: Institute of Technical Mechanics.

4. Lykov, A.V. (1967). Theory of Heat Conduction. Moscow: Vysshaya Shkola.

\section{AHOTАЦІЯ / АННОТАЦИЯ / ABSTRACT}

О.І. Брунеткін. Інтегральний підхід до вирішення задач динаміки рідини і теплообміну. Розглянуто альтернативний, по відношенню до поширеного “диференціального”, “інтегральний” підхід у вирішенні завдань динаміки. Замість спрощення диференціальної, і відповідно складної, математичної моделі до рівня можливості ії вирішення розглядається опис досліджуваного процесу за допомогою загальних інтегральних (найбільш простих) балансових співвідношень законів збереження з подальшою їх деталізацією (ускладненням) до рівня необхідної точності одержуваного рішення. Можливості такого підходу проілюстровані на прикладах: рішення задач визначення власної частоти коливань рідини з вільною поверхнею в ємностях різних форм при їх різній орієнтації в полі масових сил; рішення задачі прогріву тіл різної форми (нескінченна пластина, нескінченний циліндр, куля).

Ключові слова: інтегральний підхід, динаміка рідини, нестаціонарні задачі нагріву тіл, критерії подібності, числа подоби.

А.И. Брунеткин. Интегральный подход к решению задач динамики жидкости и теплообмена. Рассмотрен альтернативный, по отношению к распространенному “дифференциальному”, “интегральный” подход в решении задач динамики. Вместо упрощения дифференциальной, и соответственно сложной, математической модели до уровня возможности ее решения рассматривается описание исследуемого процесса с помощью общих интегральных (наиболее простых) балансовых соотношений законов сохранения с последующей их детализацией (усложнением) до уровня необходимой точности получаемого решения. Возможности такого подхода проиллюстрированы на примерах: решения задач определения собственной частоты колебаний жидкости со свободной поверхностью в емкостях различных форм при их различной ориентации в поле массовых сил; решения задачи прогрева тел различной формы (бесконечная пластина, бесконечный цилиндр, шар).

Ключевые слова: интегральный подход, динамика жидкости, нестационарные задачи нагрева тел, критерии подобия, числа подобия. 
A.I. Brunetkin. Integrated approach to solving the fluid dynamics and heat transfer problems. Considered is an alternative, in relation to the widely used "differential" one, "integrated" approach to solving the dynamics problems. Instead of simplifying the differential and thus complicated mathematical model to the level of a possible solution, we propose the studied process description using general integral (the most simple) balance relations of conservation laws with further detailed exposition (complication) to the required accuracy level of the resulting solutions. The approach possibilities are illustrated: with the example of solving the problem of determining the liquid fluctuation natural frequency when a free surface in tanks of various forms placed with heating different orientations in the field of mass forces; and with the example of solving the problem of various shapes' bodies (infinite plate, infinite cylinder, sphere).

Keywords: integrated approach, fluid dynamics, dependent problems of heating bodies, similarity criteria, similarity factors.

Reviewer Dr. techn. sciences, Prof. Odesa nat. polytechnic univ. Maksimov M.V.

Received October 30, 2014 